\title{
The impact of water quality on informally-declared heritage sites: a preliminary study
}

\author{
AT Vos ${ }^{1 *}$ (co-author) and S Cawood ${ }^{2}$ (co-author) \\ ${ }^{1}$ Centre for Environmental Management, University of the Free State, PO Box 339, Bloemfontein, 9300, South Africa \\ ${ }^{2}$ Centre for Africa Studies, University of the Free State, PO Box 339, Bloemfontein, 9300, South Africa
}

\begin{abstract}
The current study is an attempt to gauge the impact of water quality on 2 sacred sites in the eastern Free State, Mautse and Motouleng, which are informally-declared heritage sites, as well as the consequent implications for matters of living heritage as pertaining to the specific sites. The informally-constituted communities at the sacred sites are dependent on freshwater sources where water use, sanitation and waste disposal are unmanaged activities. The sustainability of informally-declared heritage sites may be uncertain due to factors relating to water quality. Water samples were collected for physical, chemical and biological analyses. The latter comprised algal and bacterial analyses which included testing for concentrations of faecal coliforms, where concentrations above $20 \mathrm{cfu} / 100 \mathrm{~m} \ell$ indicates a significant risk of infectious disease transmission (domestic use) and concentrations above $200 \mathrm{cfu} / 100 \mathrm{~m} \ell$ points to a significant infection risk for young livestock. Water quality is discussed in terms of human, animal and ecological risk, which may threaten the heritage and the economic subsistence based on the heritage at both sites.
\end{abstract}

Keywords: water quality, heritage, informally-declared heritage sites, faecal coliforms

\section{Introduction}

Access to clean water is a fundamental human need and is also enshrined in the Bill of Rights (The Constitution of the Republic of South Africa, Act No. 108 of 1996) as a basic human right. Water quality is a cornerstone of environmental conservation in South Africa, and in its preamble the National Water Act (Act No. 36 of 1998) recognises '...that the protection of the quality of water resources is necessary to ensure sustainability of the nation's water resources in the interests of all water users'. This study is concerned with water quality at informally-declared heritage sites in the interests of the heritage practitioners using the sites as well as the surrounding environment. Informally-declared heritage sites are defined within the parameters of this study as sites of living heritage where heritage is actively practised, although the sites are not declared and managed within the terms of the National Heritage Resources Act (NHRA).

The heritage sites of interest are sacred sites in the eastern Free State Province, i.e. Mautse, a sacred valley, and Motouleng, a sacred cave. The sites are places of pilgrimage for the purpose of performing various rituals and are repositories of vast resources of living heritage, including undocumented oral histories and indigenous knowledge. The act of pilgrimage leads to 'communitas', a process of spontaneous and egalitarian community building at the sacred sites, removed from the hierarchies and social and cultural class systems of everyday life (Eade and Sallnow, 1991). While the sites are important spiritual and cultural loci, they also fulfil a more pragmatic economic function. A number of individuals are

This paper was originally presented at the 2010 Southern African Young Water Professionals Conference, Pretoria, 19-20 January 2010.

* To whom all correspondence should be addressed.

용 +2751 401 3938/2863; fax: +2751 4012629 ; e-mail: VosAT@ufs.ac.za dependent on the sites for their economic survival, among others, the sangomas or traditional healers and prophets who practise at the sites. Both sites transect several farms of mixed farming practices including animal husbandry (cattle and horses), eco-tourism and grain cultivation. One of these farms has been declared as a nature reserve by the Department of Environmental Affairs, and has also been declared as a national heritage site (No. 199) because of the incidence of rare African bamboo in a valley adjacent to the sacred valley of Mautse.

People travel from all over South Africa to these sites to consult with the indigenous practitioners or to fulfil a spiritual or religious quest. Certain groups or individuals remain at the sites for a brief period of time, while others reside at the sites on a more permanent basis and only leave the sites briefly from time to time. The user and practitioner communities using the sites constitute informal communities with unique hierarchies and protocols that transcend the community boundaries of the extant world. These informallyconstituted communities at the sacred sites are dependent on freshwater sources, where water use, sanitation and waste disposal are all unmanaged activities.

The National Heritage Resources Act (No. 25 of 1999) earmarked sources of living heritage as part of the national estate to 'enable and encourage communities to nurture and conserve their legacy so that it may be bequeathed to future generations' (The National Heritage Resources Act, No. 25 of 1999). According to the NHRA (The National Heritage Resources Act, No. 25 of 1999), living heritage is understood to comprise the 'intangible aspects of inherited culture' including cultural tradition, oral histories, performance, ritual, popular memory, skills and techniques, indigenous knowledge systems, and the holistic approach to nature, society and social relationships. Unfortunately, the sustainability of these informally-declared heritage sites may be uncertain due to environmental factors, specifically water quality, an aspect underrepresented in matters of living heritage. 


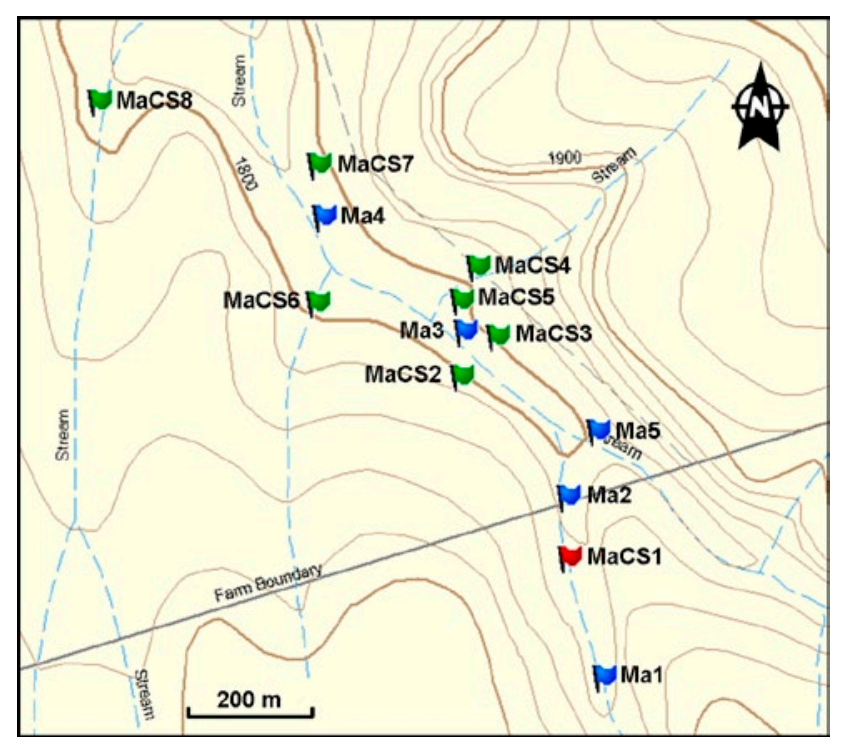

Map 1

Topographical map (Department of Rural Development and Land Reform, Chief Directorate: Surveys and Mapping) showing the sampling sites (Ma) and the sites of cultural significance (CS) at Mautse. Site Legend: Water sampling sites (blue flag): Above Tempeleng (Ma1), Below Tempeleng (Ma2), Below Yunivesithi (Ma3), Downstream of Monica's (Ma4), and Diepsloot (Ma5). CS sites (red/green flag): Tempeleng (MaCS1), Masiheng (MaCS3), Yunivesithi (MaCS5), and Monica's (MaCS6).

The current study is an attempt to gauge the impact of water quality on the pertinent sacred sites, which are informally-declared heritage sites, as well as the implication for matters of living heritage as pertaining to the specific sites. The investigation of matters of water quality and its relationship to informally declared heritage sites form part of a larger project funded by the National Heritage Council (NHC) entitled 'Heritage Resources at Sacred Sites in the Eastern Free State: Oral Histories and the Cultural Uses of Clay'. Water quality will be investigated through physical, chemical and biological analyses and the results will be interpreted in terms of human, environmental and animal risk factors.

\section{Materials and methods}

\section{Study sites}

The 2 study sites that were selected are Mautse (S 28.66228 E 28.00902 ${ }^{\circ}$ ) and Motouleng (S 28.57998 ${ }^{\circ}$ E $28.38059^{\circ}$ ). The turnoff to Mautse ( $\pm 8 \mathrm{~km}$ gravel road) is found $\pm 19 \mathrm{~km}$ on the Rosendal road turnoff (R70) from Ficksburg in the eastern Free State. At Mautse (Map 1), the various sites of cultural significance (CS) are scattered throughout the surrounding valley. Five sampling sites (Mal - 5) were chosen in 2 of the streams in the valley with an average depth of around 10 to $20 \mathrm{~cm}$, consisting mostly of bedrock as substrate. Sampling started upstream from Tempeleng continuing to a point downstream of Monica's Cave. Diepsloot (Ma5) flows into the stream from a tributary between Below Tempeleng (Ma2) and Below Yunivesithi (Ma3). The sampling streams, with others, form part of the small headwater streams of the Moolmanspruit. Tempeleng (MaCS1) is considered a particularly sacred place within the sacred valley of Mautse and is situated alongside one of the streams below an overhang. When the water levels are high, the stream forms a

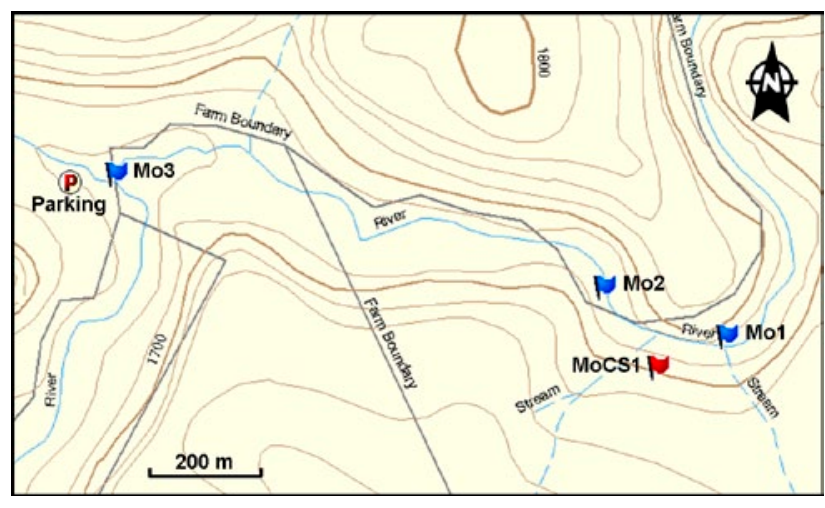

Map 2

Topographical map (Department of Rural Development and Land Reform, Chief Directorate: Surveys and Mapping) showing the sampling sites (Mo) and the sites of cultural significance (CS) at Motouleng. Site Legend: Water sampling sites (blue flag): Upstream of Cave (Mo1), Downstream of Cave (Mo2), and Near Parking (Mo3). CS sites (red/green flag): Cave (MoCS1).

waterfall into a large pool where baptism and healing rituals take place regularly, but especially during orthodox religious festivals such as Easter, as well as during traditional initiation rites, although the researchers have witnessed the use of the sacred pool for household purposes as well.

The turnoff to Motouleng ( $\pm 5 \mathrm{~km}$ of a gravel farm road) is found at Surrender Hill, $\pm 14 \mathrm{~km}$ from Clarens on the road to Fouriesburg (R711). At Motouleng (Map 2), the various sites of CS pertaining to the current study are all found in the small area of the Cave. Here, 3 sampling sites (Mo1 to 3) were selected on the Klein Caledon River that flows past the cave with an average depth around 30 to $60 \mathrm{~cm}$. The substrate of the Klein Caledon River is a mixture of bedrock, boulders, cobble, gravel and sand. The sampling started upstream from the cave and ended downstream of it, near the parking area. The Little Caledon River flows through agricultural land upstream and downstream of the site.

\section{Methods}

During June 2009 (8 to 9) and August 2009 (19 to 20), in situ measurements were taken while subsurface samples $(2 \ell)$ were taken from the shore and brought to the different laboratories for further physical and chemical analyses. Samples for bacterial analysis were also taken at the sampling points. The samples were kept on ice and stored in a refrigerator $(\leq 5$ to $0^{\circ} \mathrm{C}$ ) until it could be analysed in the laboratory. At Mautse, Above Tempeleng (Mal) and Diepsloot (Ma5) were sampled only during August 2009. The results from the June 2009 sampling suggested the inclusion of additional sampling points, i.e. Above Tempeleng (Ma1) and Diepsloot (Ma5), to specifically gauge the impact of Tempeleng. Sampling was performed from the farthest site upstream to the farthest site downstream between 11:00 and 14:00.

The water temperature $\left({ }^{\circ} \mathrm{C}\right)$, concentration of dissolved oxygen $(\mathrm{mg} / \ell)$, and percentage of saturation $\left(\mathrm{O}_{2} \%\right)$ were measured in situ with a YSI Model 85 oxygen, conductivity, salinity, temperature meter. The $\mathrm{pH}$ was measured in situ with a Eutech Instruments CyberScan $\mathrm{pH} 110$ meter $\left(\mathrm{pH} / \mathrm{mV} /{ }^{\circ} \mathrm{C} /{ }^{\circ} \mathrm{F}\right.$ with RS232) at each site. Turbidity (clarity), a measurement of the concentration of suspended solids (organic, inorganic and biological material in the water), was determined in a laboratory 
with an Aqua Lytic Turbidimeter AL 1000 and is expressed as Nephelometric Turbidity Unit (NTU). The sampling points were recorded using a handheld GPS (Garmin: eTrex Vista Personal Navigator GPS) during sampling.

Dissolved reactive ortho-phosphate $\left(\mathrm{PO}_{4}-\mathrm{P}\right)$ (an indication of eutrophication) was determined using $100 \mathrm{~m} \ell$ water filtered through a Munktell Glass-Microfibre filter paper (MGC grade), together with the Stannous Chloride Method as described in Standard Methods (2005). A Beijing Rayleigh Analytical Instrument Corp. VIS-7220 spectrophotometer was used.

The following salts were measured by the Institute for Groundwater Studies (IGS) at the University of the Free State using a Perkin Elmer Optima 300 DV Inductively Coupled Plasma (ICP) Spectrometer: Calcium $\left(\mathrm{Ca}^{2+}\right)$, Chloride $\left(\mathrm{Cl}^{1-}\right)$, Magnesium $\left(\mathrm{Mg}^{2+}\right)$, Palk and Malk, Potassium $\left(\mathrm{K}^{1+}\right)$, Sodium $\left(\mathrm{Na}^{1+}\right)$, Sulphate $\left(\mathrm{SO}_{4}^{2-}\right)$, Ammonium-nitrogen $\left(\mathrm{NH}_{4}-\mathrm{N}\right)$, Nitrate-nitrogen $\left(\mathrm{NO}_{3}-\mathrm{N}\right)$, and Phosphate $\left(\mathrm{PO}_{4}^{2-}\right)$. All of the above were included in the calculation of total dissolved salts (TDS); $\mathrm{NH}_{4}-\mathrm{N}$ plus $\mathrm{NO}_{3}-\mathrm{N}$ was used to indicate dissolved inorganic nitrogen (DIN), and $\mathrm{PO}_{4}{ }^{2+}$ was used to indicate dissolved inorganic phosphorus (DIP). The Institute for Groundwater Studies (IGS) also measured the following by using an ICP Spectrometer: Total Nitrogen (TN) and Total Phosphates (TP).

The bacterial concentrations for faecal coliforms and E. coli were determined by the IGS, using the IDEXX Colilert Method.

A modified methanol method described by Sartory and Grobbelaar (1984) was used to measure Chlorophyll- $a$ utilising a VIS-7220 spectrophotometer. The identification of algal species was done with an inverted Zeiss Light Microscope after fixation with formaldehyde (final concentration of $2 \%$ ) and stored in a sedimentation chamber for at least $24 \mathrm{~h}$.

All results are based on 2 samples per sampling location at the 2 sacred sites, taken during June and August 2009. The samples of each sampling location were treated as separate data sets, which comprise only 2 measurements at this time. The current article therefore reports on preliminary results of a continuous study and the calculation of standard deviation is consequently premature.

\section{Results}

The water temperature at Mautse showed seasonal trends where the temperature in June 2009 was lower than that of August 2009. The sampling points that were in the shade most of the day (Below Tempeleng (Ma2), Below Yunivesithi (Ma3) and Diepsloot (Ma5)) also showed lower temperatures than the sampling sites that received some sun during the day. The water temperature at Motouleng did not exhibit seasonality, but during August 2009 the farthest downstream sampling site (Near Parking (Mo3)) measured a higher temperature than the sites farther upstream.

The dissolved oxygen concentrations (DO; Fig. 1) at Mautse were higher during June 2009 than during August 2009, whereas at Motouleng, the $1^{\text {st }}$ sampling site, Upstream from Cave (Mo1), had higher DO concentration $(15.7 \mathrm{mg} / \ell)$ during June 2009 compared to the other 2 sampling sites; and the DO concentration was higher at Downstream from Cave (Mo2) in August $2009(14.2 \mathrm{mg} / \ell)$ in June $2009(10.8 \mathrm{mg} / \ell)$. None of the sampling sites had oxygen saturation lower than $60 \%$.

The $\mathrm{pH}$ at Mautse ranged from 7.68 to 8.73 during June and August 2009, while at Motouleng it ranged from 8.13 to 8.89. Thus the water at Motouleng was on average more alkaline than that of Mautse.
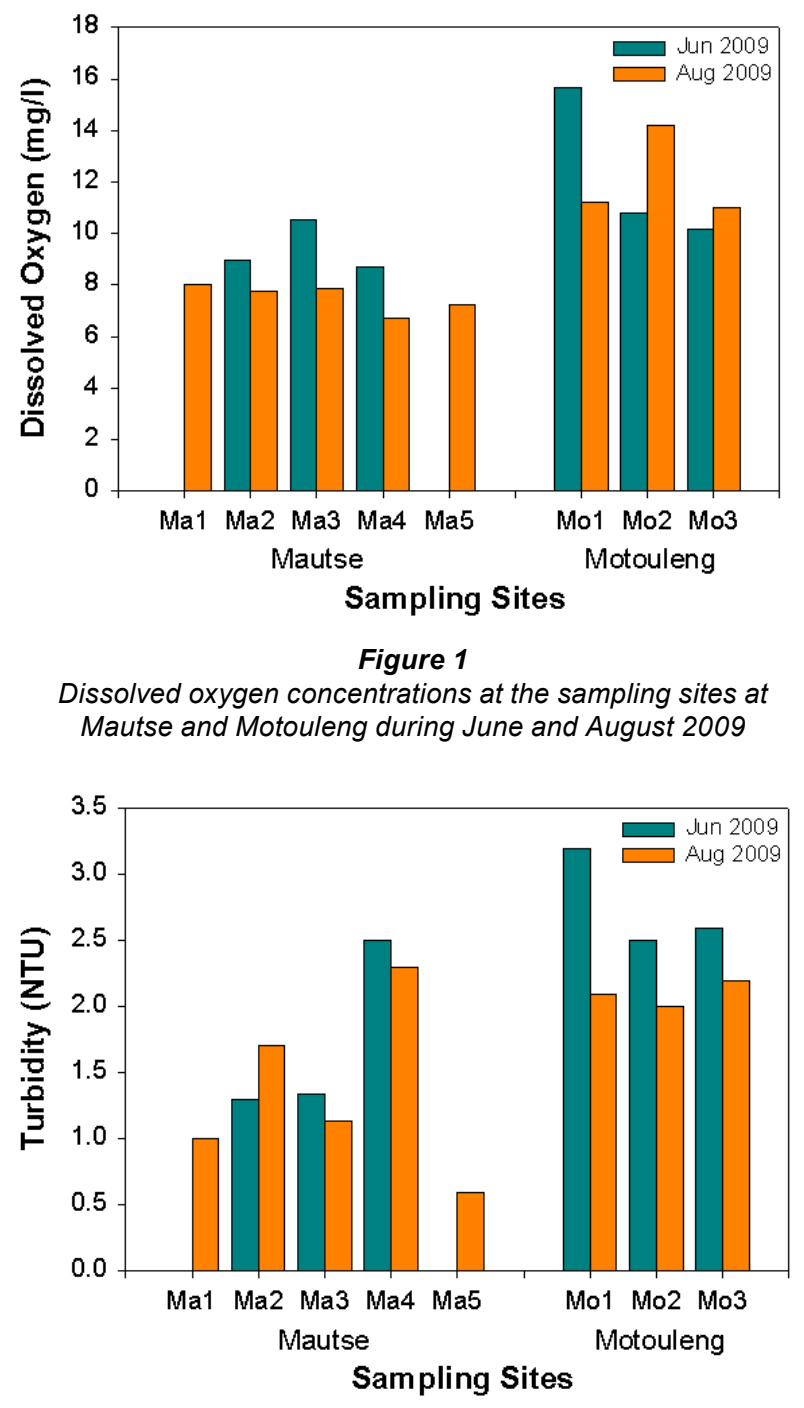

Figure 2

Turbidity at the sampling sites at Mautse and Motouleng during June and August 2009

The turbidity (Fig. 2), at the Mautse sampling sites, ranged from 0.6 to 2.5 NTU, with Diepsloot (Ma5) being the lowest during August 2009 and Downstream from Monica's (Ma4) exhibiting the highest turbidity during August 2009. At Motouleng, the turbidity was the highest during June 2009 at all the sampling sites (3.2 NTU at Upstream from Cave (Mo1)) and lowest during August 2009 (2.0 NTU at Downstream from Cave (Mo2)).

At Mautse, the dissolved inorganic phosphorus (DIP; Fig. 3a) concentrations were higher during the August 2009 sampling period, while the total phosphorus concentrations (TP, Fig. 3b) showed approximately the same pattern (TP concentrations could not be analysed at levels lower than $0.1 \mathrm{mg} / \ell$ ). At Motouleng, the DIP concentrations were higher at Upstream from Cave (Mo1) and Near Parking (Mo3), and the same pattern can be observed for the TP concentrations.

The dissolved inorganic nitrogen (DIN) concentrations (Fig. 4a) at Mautse were the highest at Above Tempeleng and Below Tempeleng (Ma1 and Ma2) for both the June and August 2009 sampling periods. The total nitrogen (TN) concentrations (Fig. 4b), however, were highest at Below Tempeleng (Ma2; $15 \mathrm{mg} / \ell$ ) during August 2009, and were also high downstream. 


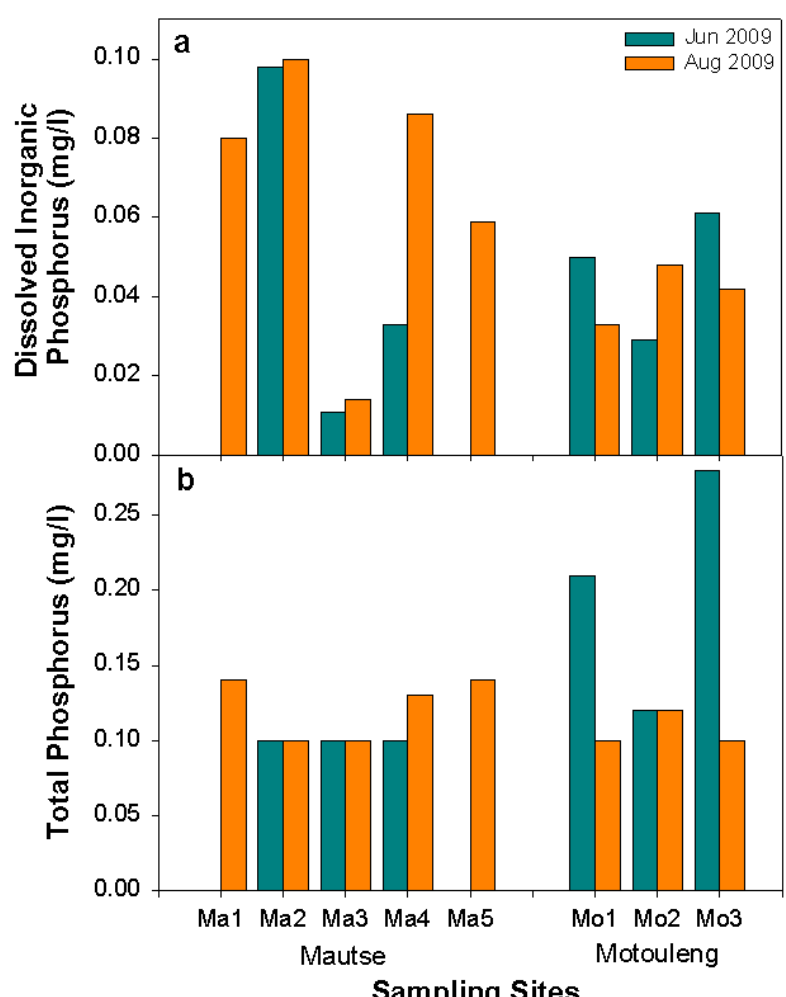

Figure 3

The (a) dissolved inorganic phosphorus and (b) total phosphorus concentrations at the sampling sites at Mautse and Motouleng during June and August 2009

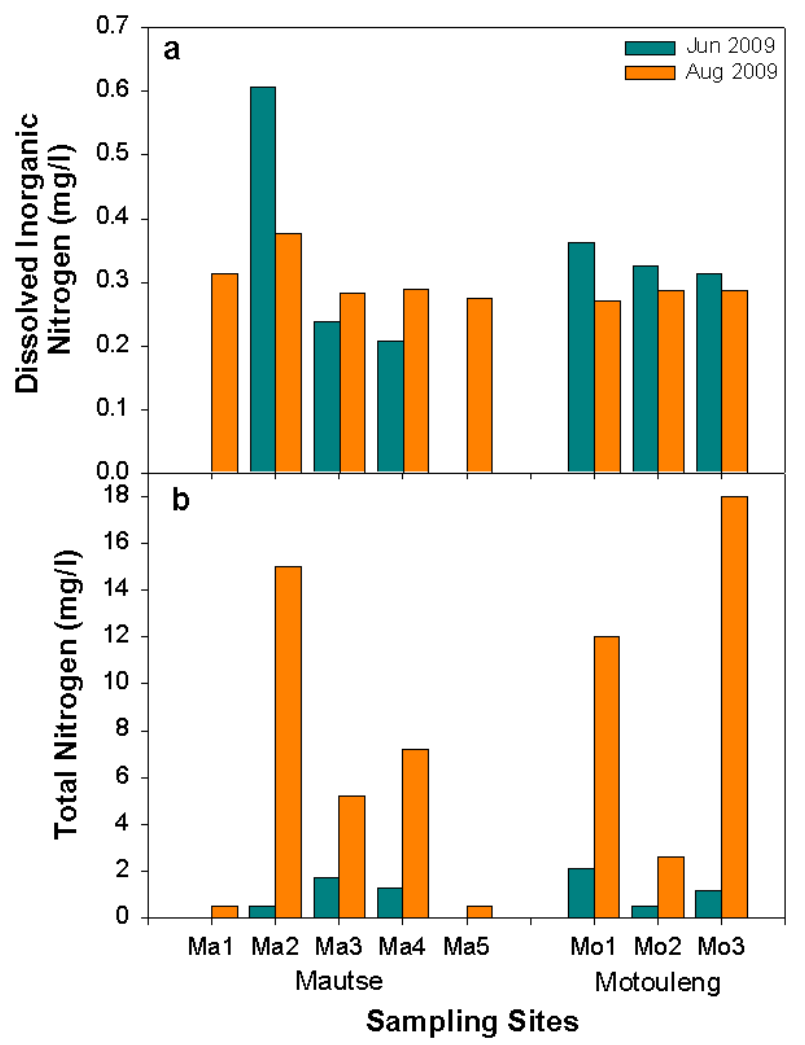

Figure 4

The (a) dissolved inorganic nitrogen and (b) total nitrogen concentrations at the sampling sites at Mautse and Motouleng during June and August 2009

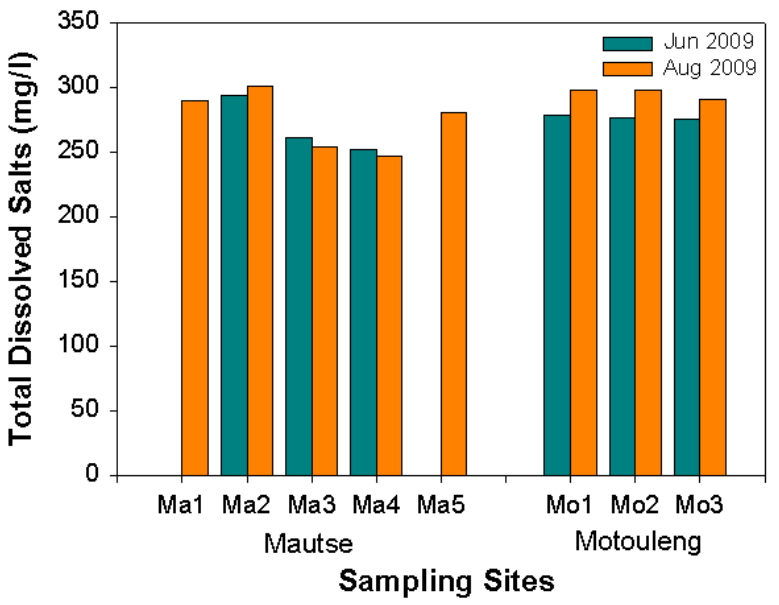

Figure 5

Total dissolved salt concentrations at the sampling sites at Mautse and Motouleng during June and August 2009

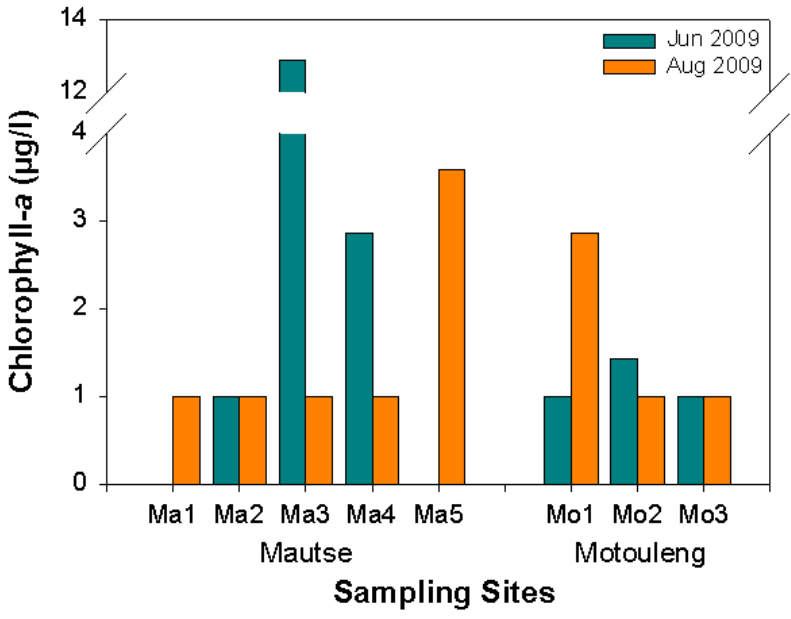

Figure 6

The Chlorophyll-a concentrations at the sampling sites at Mautse and Motouleng during June and August 2009

The DIN concentrations at Motouleng were the highest at the sampling sites in June 2009, while the TN concentrations were the highest in August 2009.

The total dissolved salts concentrations (TDS; Fig. 5) at each sampling site at Mautse differed only slightly between the June and August 2009 sampling. A decrease is observed along the stream gradient. The TDS concentrations at Motouleng were relatively similar at all 3 sampling sites (Mo1-3) during June 2009, as well as during August 2009. The TDS concentrations for August 2009 were higher than that for June 2009.

The chlorophyll- $a$ (chl- $a$ ) concentrations (Fig. 6) at Mautse were all below $4 \mu \mathrm{g} / \ell$ except for the June 2009 sample of Below Yunivesithi (Ma3), which was $13 \mu \mathrm{g} / \ell$. The chl- $a$ concentrations at Motouleng also fell below $4 \mu \mathrm{g} / \ell$, with Upstream from Cave (Mol) at $3 \mu \mathrm{g} / \ell$.

The phytoplankton concentrations at Mautse (Table 1) were all below 520 cells $/ \mathrm{m} \ell$, with the highest concentrations occurring during August 2009. At Motouleng, the phytoplankton concentrations were between 500 and $1000 \mathrm{cells} / \mathrm{m} \ell$, on average higher than that of Mautse. The phytoplankton concentrations at Motouleng (Table 2) were also higher during August 2009 than during June 2009. Both the sites were dominated 


\begin{tabular}{|c|c|c|c|c|c|c|c|c|c|c|}
\hline \multicolumn{11}{|c|}{$\begin{array}{l}\text { Table } 1 \\
\text { The algal composition of the sampling sites }(\text { Ma1 }-5) \text { at Mautse during June and August } 2009\end{array}$} \\
\hline \multirow{2}{*}{\begin{tabular}{r|} 
Sampling site \\
Date (2009)
\end{tabular}} & \multicolumn{2}{|c|}{ Ma1 } & \multicolumn{2}{|c|}{ Ma2 } & \multicolumn{2}{|c|}{ Ma3 } & \multicolumn{2}{|c|}{ Ma4 } & \multicolumn{2}{|c|}{ Ma5 } \\
\hline & Jun & Aug & Jun & Aug & Jun & Aug & Jun & Aug & Jun & Aug \\
\hline $\begin{array}{l}\text { DIVISIONS } \\
\text { GENERA }\end{array}$ & $\begin{array}{c}\text { cells/ } \\
\text { me }\end{array}$ & $\begin{array}{c}\text { cells/ } \\
\mathrm{m} \ell\end{array}$ & $\begin{array}{c}\text { cells/ } \\
\text { me }\end{array}$ & $\begin{array}{c}\text { cells } \\
\text { me }\end{array}$ & $\begin{array}{c}\text { cells/ } \\
\text { me }\end{array}$ & $\begin{array}{c}\text { cellsl } \\
\text { me }\end{array}$ & $\begin{array}{c}\text { cells/ } \\
\text { me }\end{array}$ & $\begin{array}{c}\text { cellsl } \\
\text { me }\end{array}$ & $\begin{array}{c}\text { cells/ } \\
\text { me }\end{array}$ & $\begin{array}{c}\text { cells/ } \\
\mathrm{m} \ell\end{array}$ \\
\hline CYANOPHYTA & $\mathbf{0}$ & 74 & 74 & $\mathbf{0}$ & $\mathbf{0}$ & $\mathbf{0}$ & $\mathbf{0}$ & $\mathbf{0}$ & $\mathbf{0}$ & $\mathbf{0}$ \\
\hline Oscillatoria & & 74 & 74 & & & & & & & \\
\hline BACILLARIOPHYTA & $\mathbf{0}$ & $\mathbf{0}$ & 222 & 369 & 222 & 370 & 294 & 296 & $\mathbf{0}$ & $\mathbf{0}$ \\
\hline Cocconeis & & & 74 & & 74 & & & & & \\
\hline Cyclotella. & & & & 74 & & 74 & & 74 & & \\
\hline Navicula & & & & 147 & 74 & & & 74 & & \\
\hline Nitzschia & & & 74 & 74 & 74 & 74 & 147 & 74 & & \\
\hline Pinnularia & & & & 74 & & & & & & \\
\hline Stauroneis & & & & & & 74 & & & & \\
\hline Synedra & & & 74 & & & 74 & 147 & 74 & & \\
\hline CHLOROPHYTA & 0 & 74 & 221 & 148 & 74 & 74 & $\mathbf{0}$ & 74 & $\mathbf{0}$ & 74 \\
\hline Chlamydomonas & & & & 74 & 74 & 74 & & 74 & & \\
\hline Chlorella & & 74 & 147 & & & & & & & 74 \\
\hline Monoraphidium & & & 74 & & & & & & & \\
\hline Scenedesmus & & & & 74 & & & & & & \\
\hline TOTAL: & $\mathbf{0}$ & 148 & 517 & 517 & 296 & 444 & 294 & 370 & $\mathbf{0}$ & 74 \\
\hline
\end{tabular}

\begin{tabular}{|c|c|c|c|c|c|c|}
\hline \multicolumn{7}{|c|}{$\begin{array}{l}\text { Table } 2 \\
\text { The algal composition of the sampling sites (Mo1 - 3) } \\
\text { at Motouleng during June and August } 2009\end{array}$} \\
\hline \multirow{2}{*}{\begin{tabular}{r|} 
Sampling site \\
Date (2009)
\end{tabular}} & \multicolumn{2}{|c|}{ Mo1 } & \multicolumn{2}{|c|}{ Mo2 } & \multicolumn{2}{|c|}{ Mo3 } \\
\hline & Jun & Aug & Jun & Aug & Jun & Aug \\
\hline \begin{tabular}{|l|} 
DIVISIONS \\
GENERA
\end{tabular} & $\begin{array}{c}\text { cells/ } \\
\text { me }\end{array}$ & $\begin{array}{c}\text { cells/ } \\
\text { me }\end{array}$ & $\begin{array}{c}\text { cells/ } \\
\text { me }\end{array}$ & $\begin{array}{c}\text { cells/ } \\
\text { me }\end{array}$ & \begin{tabular}{|c|} 
cells/ \\
me
\end{tabular} & $\begin{array}{c}\text { cells } \\
\text { me }\end{array}$ \\
\hline CYANOPHYTA & $\mathbf{0}$ & 74 & $\mathbf{0}$ & $\mathbf{0}$ & $\mathbf{0}$ & $\mathbf{0}$ \\
\hline Oscillatoria & & 74 & & & & \\
\hline BACILLARIOPHYTA & 589 & 587 & 368 & 515 & 368 & 588 \\
\hline Cocconeis & & & 74 & & 74 & \\
\hline Cyclotella & 74 & & & 74 & & \\
\hline Cymbella & & & 74 & & 74 & \\
\hline Gomphonema & 74 & & & & & \\
\hline Melosira & 74 & 74 & & 74 & & 74 \\
\hline Navicula & 147 & & & 147 & & 74 \\
\hline Nitzschia & 220 & 513 & 220 & 220 & 220 & 440 \\
\hline CHLOROPHYTA & 74 & 294 & 148 & 74 & 147 & 74 \\
\hline Carteria & & 74 & & & & \\
\hline Chlamydomonas & & & 74 & 74 & & 74 \\
\hline Chlorella & 74 & 220 & 74 & & 147 & \\
\hline EUGLENOPHYTA & $\mathbf{0}$ & $\mathbf{0}$ & $\mathbf{0}$ & 74 & $\mathbf{0}$ & $\mathbf{0}$ \\
\hline Trachelomonas & & & & 74 & & \\
\hline CHRYSOPHYTA & $\mathbf{0}$ & $\mathbf{0}$ & $\mathbf{0}$ & 74 & $\mathbf{0}$ & $\mathbf{0}$ \\
\hline Mallomonas & & & & 74 & & \\
\hline TOTAL: & 663 & 955 & 516 & 737 & \begin{tabular}{|l|}
515 \\
\end{tabular} & 662 \\
\hline
\end{tabular}

by the Bacillariophyte (diatoms) genera, as well as a few Chlorophyte (green algae) genera. Various filamentous algae species were found on the benthic substrates of sampling sites at both Mautse and Motouleng.

At Mautse, there were significant variations in faecal coliform concentrations (Fig. 7a) among the sampling sites and between each site's sampling dates. Below Tempeleng (Ma2) had the highest faecal coliform count of $1203 \mathrm{cfu} / 100 \mathrm{m \ell}$, of which $921 \mathrm{cfu} / 100 \mathrm{~m} \ell$ were Escherichia coli (Fig. 7b). At

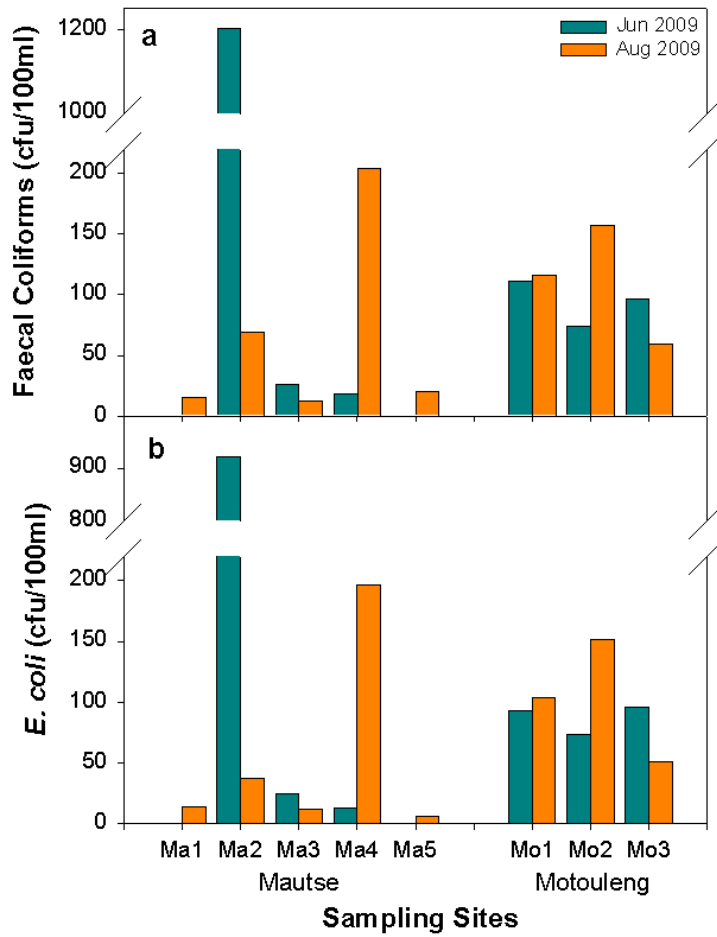

Figure 7

The (a) faecal coliform and (b) Escherichia coli concentrations at the sampling sites at Mautse and Motouleng during June and August 2009

Motouleng, the variations in the faecal coliform concentrations were lower between the sampling sites and the sampling dates. At both sites, the faecal coliforms mostly consisted of $E$. coli.

\section{Discussion}

The seasonal trend found in the water temperature at Mautse can be ascribed to the lower air temperature in the winter, 
warming towards spring (Walling and Webb, 1992); therefore the water was warmer during the August 2009 sampling period. The cooler water at sampling sites Mo1 and Mo2 could be ascribed to interflow springs that have low water temperatures. The warmer water at sampling site Mo3 could be the result of the sun's radiation on the water, while sampling sites Mol and Mo2 are situated in the river canyon and do not receive ample sunlight.

At Mautse, the higher DO concentrations during June 2009 can be attributed to the higher solubility of oxygen in cooler water than in warmer water (Dallas and Day, 2004; Davies and Day, 1998). At Motouleng Site Mo1, the higher DO concentration during June 2009 could also be a result of the solubility of oxygen in the water. Even though the algal concentration was higher during August 2009, the cooler water temperature could be inhibiting photosynthesis by lowering the metabolic rates of the algae (Davies and Day, 1998; Horne and Goldman, 1994). At Sites Mo2 and Mo3, the increase in algal concentration could be the cause of the higher DO concentrations during August 2009; more algae results in more photosynthesis, creating more DO (Horne and Goldman, 1994).

The high $\mathrm{pH}$ at both Mautse and Motouleng could be ascribed to the high DO concentrations at the sites and likely good buffering capacity (Dallas and Day, 2004). It also concurs with the notion that rivers in the eastern part of the country have a $\mathrm{pH}$ of $>7$ (Allanson, 1995).

At Mautse, the bedrock substrate at the upper sampling sites (Ma1 to 3 and Ma5) could be the main reason for the low turbidity at these sampling sites, as there are no sedimentary particles to be suspended in the shallow water column. Sampling site Ma4 has gravel and sand as part of the substrate and that is likely to be the reason why its turbidity is higher (Dallas and Day, 2004). The average turbidity at Motouleng is much higher than at Mautse, probably due to higher sediment levels in the river and higher levels of phytoplankton in suspension.

The DIP concentration at sampling sites Mal and Ma5 is thought to be due to natural influences since little or no human impact was found above these sampling sites. The higher DIP concentrations at Sites Ma2 and Ma4 could be as a result of human impact/activities, as Ma2 lies downstream of Tempeleng (MaCS1), a site of particular cultural significance. At Site Ma4 it was observed that people used the water to clean containers for household use. Dissolved inorganic phosphorous concentrations of $>0.01 \mathrm{mg} / \ell$ is seldom found in non-polluted (nonimpacted) waters (Dallas and Day, 2004; Horne and Goldman, 1994). The TP concentrations indicated that at Mautse most of the phosphorus is available as DIP and available for the use of plants (aquatic or riparian).

The DIP concentrations at Motouleng varied less ( 0.03 to $0.06 \mathrm{mg} / \ell$ in June 2009 and 0.03 to $0.05 \mathrm{mg} / \ell$ in August 2009) over the sampling stretch of the river, although there was less impact during June 2009 on the aquatic environment directly downstream of the cave (Mo2) than during August 2009. The number of people found staying at this site during the period was lower than at Mautse, due to the fact that Mautse, with its open spaces, can accommodate more people than Motouleng with its enclosed space under a sandstone overhang. The river at Motouleng also had a higher volume than the stream at Mautse. The high TP concentrations during June 2009, compared to August 2009, probably indicates that during June 2009 most of the phosphorus was present as inorganic debris in the water or was bound to sediment (the water was more turbid during June 2009) (Dallas and Day, 2004; Webb and Walling,
1992), while in August 2009 the phosphorus was represented to some extent by its soluble form, while the rest was fixed in organic debris or aquatic plants. During August 2009, the riparian (re)growth could also be a contributor to the decreasing DIP concentrations in the water.

The DIN concentrations at Mautse did not fluctuate as much as the DIP concentrations along the stream's downstream gradient. The higher DIN concentrations at Site Ma2, downstream from Tempeleng, are an indication of possible pollution in its upstream region. At Ma2, the DIN concentration mostly consisted of nitrate $\left(\mathrm{NO}_{3}^{-}\right)$while the DIN concentrations at the other sampling sites consisted of ammonium $\left(\mathrm{NH}_{4}^{+}\right)$. There was also a very high level of $\mathrm{TN}$ at $\mathrm{Ma} 2$ that confirms the possibility of pollution upstream of the sampling site.

The DIN concentrations at Motouleng remain more constant (average of $\pm 0.3 \mathrm{mg} / \ell$ ) over the stretch of river sampled during June 2009, although the DIN concentration was higher in June than August 2009. During August 2009, the increase in algal concentration most probably contributed to the decrease in DIN concentration, via absorption for growth. The TN concentrations at Sites Mo1 and Mo3 were very high and it was observed that there was a large amount of organic matter present in the sediment (gravel and sandy substrate), especially upstream of Site Mo3, that could contribute to the high TN concentrations.

According to the Target Water Quality Range (TWQR) for inorganic phosphorus in the South African Water Quality Guidelines for Aquatic Ecosystems (DWAF, 1996a), the water at both sites is in poor condition (eutrophic), which could in future, result in nuisance algal growth resulting in problems for the environment and the people living at the sites. Inorganic nitrogen concentrations of unimpacted aerobic surface waters in South Africa are usually below $0.5 \mathrm{mg} / \ell$ (DWAF, 1996a). Most of the sampling sites at the 2 study areas (Mautse and Motouleng) fell below the above-mentioned margin.

The TDS concentration at both Mautse and Motouleng was approximately $300 \mathrm{mg} / \ell$ or lower. The range at Mautse was between $302 \mathrm{mg} / \ell$ and $247 \mathrm{mg} / \ell$ and between $298 \mathrm{mg} / \ell$ and $276 \mathrm{mg} / \ell$ at Motouleng during the 2 sampling periods. According to Allanson (1995) the TDS concentration of natural surface water in this area falls below $300 \mathrm{mg} / \ell$, therefore placing the TDS concentrations within the natural range.

The phytoplankton chl- $a$ concentrations at both Mautse and Motouleng were all below $4 \mu \mathrm{g} / \ell$ (except Ma3 during June 2009) and, according to Walmsley (2000), Dodds et al. (1998) and Chapman (1996), the trophic ranges are either oligotrophic (good) or mesotrophic (fair) for the sampling sites, but can deteriorate if chl- $a$ concentrations (and that of algae) increase as temperatures increase, as there are enough nutrients to enable this to occur (Reynolds, 1992).

The algal concentrations (phytoplankton) at Mautse and Motouleng ranged between 148 cells $/ \mathrm{m} \ell$ and 955 cells $/ \mathrm{m} \ell$, and the assemblages mostly consisted of Bacillariophytes (diatoms) and Chlorophytes (green algae). However, at various sampling sites (Ma1, Ma2 and Mo1) Cyanophytes (blue-green algae; Oscillatoria sp.) occurred, and with high nutrients and warmer temperatures, this may became a nuisance as algal concentrations increase (Reynolds, 1992).

According to the Department of Water Affairs (formerly the Department of Water Affairs and Forestry (DWAF, 1996b)), faecal coliform bacteria are being used as an indicator of faecal pollution and E. coli is a highly specific faecal pollution indicator of human and warm-blooded animal origin. At Mautse, there were very high concentrations of both coliforms at Site Ma2 during 
June 2009 as well as at Site Ma4 during August 2009, indicating possibly high levels of faecal pollution at these sampling sites. At Motouleng, there was an average faecal coliform concentration of about $100 \mathrm{cfu} / 100 \mathrm{~m} \ell$, most of which consisted of $E$. coli (as found at Mautse). There are no specified quality ranges for full body contact apart from recreational use (swimming) for faecal coliforms and/or E. coli, according to DWAF (1996b), where 0 to $130 \mathrm{cfu} / 100 \mathrm{~m} \ell$ poses a risk of gastrointestinal illness. However, WRC (1998) suggested that for faecal coliform concentrations ranging from 10 to $100 \mathrm{cfu} / 100 \mathrm{~m} \ell$ slightly increased the risk of infection when bathing and that the possibility of infection at above $100 \mathrm{cfu} / 100 \mathrm{~m} \ell$ exists. For drinking water, the infection probability starts at $1 \mathrm{cfu} / 100 \mathrm{~m} \ell$.

\section{Conclusions}

Water samples were tested for physical, chemical and biological analyses and the researchers found negligible physical and chemical risk for human consumption. Water temperature fluctuation, dissolved oxygen (DO) concentration and $\mathrm{pH}$ followed natural trends and neither posed nor indicated environmental or human health risks. Dissolved oxygen concentration may, however, decline in summer months, which could add stress to the environmental health of the sites, which in turn could add risk to human and animal users.

An inverse relationship exists between total dissolved salts (TDS) and turbidity where an increase in TDS leads to a decrease in turbidity (Roos and Pieterse, 1995). A higher level of TDS therefore also impacts on the suspension of algae as biological matter in water, where the algae are therefore not suspended in the water, but settled as sediment on the substrate. As a result, water may appear clearer and the laity using the sites may therefore wrongly assume it is safe for consumption. At Mautse, the substrates mostly consist of bedrock and the water column is too shallow for the above-mentioned effect of the inverse relationship to be noteworthy. Water may still appear clear and safe due to the lack of sediment and therefore low turbidity levels. At Motouleng, however, the effect is notable because of the sedimentary substrate. At both sites, nonetheless, water may therefore appear to be clear and therefore safe to consume by lay communities unaware of underlying health risks such as bacterial infections, for instance faecal coliforms. The clarity of the water is by no means an indication of purity, but a masking effect.

Both Mautse and Motouleng, with regard to nutrient trophic levels, were found to be mesotrophic, which is classified as indicating fair water quality, although the sites were not identical. Mautse, while still being considered mesotrophic, is inclined towards eutrophic levels of nutrients, which indicates poor water quality. The sites Below Tempeleng (Ma2) and Downstream of Monica's (Ma4) are distinctly eutrophic. The sampling for this study was done during winter and the levels of phosphorus and nitrogen contributing to the eutrophic conditions of Ma2 and Ma4 may, with an increase in temperatures associated with summer months, lead to increased algal growth, possibly leading to an algal bloom including bluegreen algae of which various genera excrete toxins poisonous to animals and humans. Algae at the sites was found to pose a negligible risk for human consumption as it consisted primarily of diatoms, although it may also lead to future risk due to its siliceous cell wall (frustule), since the glass-like cell walls of diatoms may contribute to gastro-intestinal irritation.

Bacterial analysis included testing for concentrations of faecal coliforms. Concentrations above $20 \mathrm{cfu} / 100 \mathrm{~m} \ell$ indicate a significant risk of infectious disease transmission for domestic use. For human consumption, a target water quality range of $0 \mathrm{cfu} / 100 \mathrm{~m} \ell$ is desired. For livestock, concentration above $200 \mathrm{cfu} / 100 \mathrm{~m} \ell$ indicates a significant risk of infection for young livestock (DWAF, 1996c).

At Mautse, the mean concentration of faecal coliforms in June 2009 was $416 \mathrm{cfu} / 100 \mathrm{m \ell}$, while the August 2009 concentrations were significantly lower with a mean concentration of $64 \mathrm{cfu} / 100 \mathrm{~m} \ell$. In June 2009, E. coli comprised $77 \%$ of the faecal coliforms, while in August E. coli comprised $83 \%$. The June 2009 levels of bacterial concentration were dangerously high indicating health risks for recreational use and especially consumption. The major contributing site was Below Tempeleng (Ma2) with an individual faecal coliform concentration of $1203 \mathrm{cfu} / 100 \mathrm{~m} \ell(921 \mathrm{cfu} / 100 \mathrm{~m} \ell$ E. coli $)$ for June 2009 and $69 \mathrm{cfu} / 100 \mathrm{~m} \ell$ in August 2009. Based on the significant decrease from June to August it seems likely that there was a high incidence of human activity directly prior to the June sampling period.

Although the alarming concentrations of faecal coliforms decreased significantly by August 2009, the fact that they occurred in June raises pertinent questions about the use of the site, an issue which is being explored within the broader NHC Project. The sample was taken approximately $80 \mathrm{~m}$ downstream of the sacred pool at Tempeleng (MaCS1), Below Tempeleng (Ma2), and not from the pool itself, in order to refrain from interfering with the activities and sacredness of the site. The inordinately high bacterial concentration at Ma2, however, suggests the occurrence of similar concentrations at Tempeleng and the sacred pool, raising questions about the construction of sacredness and the range of activities occurring prior to June 2009. Considering the source of faecal coliforms (human and animal), the researchers question the notion that Tempeleng is a place constituted by a universal and culturetranscending construction of sacredness. While sacred rites have been witnessed at Tempeleng, it is highly probable that the same construction of sacredness is not shared by all using the specific site, as is attested to by the quality of the water.

At Motouleng, the mean concentration of faecal coliforms was $94 \mathrm{cfu} / 100 \mathrm{~m} \ell$ for June 2009 and $111 \mathrm{cfu} / 100 \mathrm{~m} \ell$ for August 2009. The individuals dwelling in or visiting the cave indicated that they used river water primarily for household washing and bathing, while drinking water is sourced from seepage within the cave itself. The stretch of river closer to the cave exhibited higher levels of faecal coliform concentrations, with E. coli above $90 \%$ for both June and August 2009 and posing a slight risk for gastro-intestinal infection for both recreational use and consumption.

The various influences on the water quality at both sites, as identified by the researchers, are domestic and cultural use, commercial agriculture and subsistence husbandry. At both Mautse and Motouleng, human influence, in the form of domestic use (Ma4) and cultural use (ritual at Ma2), appears to be the major contributor to water quality and especially the concentrations of faecal coliforms. The influence of commercial agriculture, however, seems more pronounced at Motouleng than at Mautse as the researchers observed cultivated fields and a large herd of cattle in the area surrounding Motouleng. The sacred valley of Mautse is situated in the headwater of the Moolmanspruit, and has little arable land, with subsistence husbandry apparently more prevalent at Mautse than at Motouleng.

The various influences contribute to particular risk factors, i.e. human, animal and ecological risk factors that are all interlinked and can best be understood as a cycle of risk. 
Overexploitation of water bodies by practitioners, dwellers and visitors degrades the water quality which represents ecological risk, while poor water quality conversely poses a risk to human and animal health alike. The cycle is continued when animals and humans follow unsanitary water practices, e.g. excreting in or close to the water, dumping waste (food, etc.) in the water, slaughtering animals close to or in the water or bathing and washing. All these activities create residue possibly providing nutrients and substrates for other bacteria (apart from faecal coliforms) and pathogens equally as dangerous, if not more so. Ecological risk may therefore contribute to human and animal risk, which in turn, exacerbates the ecological risk and so the cycle continues.

The sacred sites under discussion fulfil important functions to the indigenous practitioners who practise and make a living at the sites and the pilgrims who undertake a spiritual or religious quest to these sites. The sites are, however, not formally-declared heritage sites, although they are informally recognised because of the vast repositories of heritage intrinsic to the sites. The lack of formal protection has led to a situation where human activities such as waste disposal, sanitation and a lack of environmental management are escalating the degradation of the value of the sites. Ecological risk, as evidenced by the moderate to poor water quality at both sites, may invariably lead to a threat to practitioners and visitors and therefore the intrinsic living heritage of the sites. Living heritage sites, such as these, stay vital for as long as they are used for this purpose, in other words, for as long as the heritage practices continue. Should the heritage practitioners be under threat, the heritage practices will suffer and the sites will lose their intrinsic and intangible value. Not only is precious heritage lost, but countless individuals who depend on these sites and their associative heritage for economic subsistence and survival are left destitute. The environmental degradation of these sites may also adversely affect the areas surrounding them, where ecotourism plays a major economic role.

The impact of environmental factors, particularly water quality, should be considered as an important aspect when dealing with informally-declared heritage sites such as Mautse and Motouleng. Without the formal protection afforded to declared heritage sites, stakeholders of the informally-declared heritage sites should be encouraged to explore environmental management models sensitive to the informal status of these sites based on consultation, education and guidance.

\section{Acknowledgements}

We would like to thank the National Heritage Council and the Strategic Academic Cluster of the University of the Free State: Water Management in Water-Scarce Areas for the financial support of this collaboration.

\section{References}

ALLANSON BR (1995) An Introduction to the Management of Inland Water Ecosystems in South Africa. WRC Report No. TT 72/95. Water Research Commission, Pretoria, South Africa. 77 pp.

CHAPMAN D (ed.) (1996) Water Quality Assessments: A Guide to the Use of Biota, Sediments and Water in Environmental Monitoring ( $2^{\text {nd }}$ edn.) UNESCO/WHO/UNEP E\&FN Spon, London. $651 \mathrm{pp}$. URL: http://www.who.int/water_sanitation_health/en/ (Accessed 15 May 2008).

CONSTITUTION OF THE REPUBLIC OF SOUTH AFRICA. Act No. 108 of 1996. Government of South Africa.
DALLAS HF and DAY JA (2004) The Effect of Water Quality Variables on Aquatic Ecosystems: A Review. WRC Report No. TT 224/04. Water Research Commission, Pretoria, South Africa. $222 \mathrm{pp}$.

DAVIES B and DAY J (1998) Vanishing Waters. University of Cape Town Press. Cape Town. 487 pp.

DEPARTMENT OF RURAL DEVELOPMENT AND LAND REFORM, SOUTH AFRICA, CHIEF DIRECTORATE: SURVEYS AND MAPPING, South Africa - Topographical \& Recreation v 1.00. Copyright Authorisation nr 11265 LIC 745 , Avnic Trading ID 745, MapIT (Pty.) Ltd. Georigin (PTY) Ltd. CSIR.

DODDS WK, JONES JR and WELCH EB (1998) Suggested classification of stream trophic state: distributions of temperate stream types by chlorophyll, total nitrogen and phosphorus. Wat. Res. 32 (5) 1455-1462.

DWAF (DEPARTMENT OF WATER AFFAIRS AND FORESTRY, SOUTH AFRICA) (1996a) South African Water Quality Guidelines. Volume 7. Aquatic environment ( $1^{\text {st }}$ edn.; $1^{\text {st }}$ issue $)$. $159 \mathrm{pp}$.

DWAF (DEPARTMENT OF WATER AFFAIRS AND FORESTRY, SOUTH AFRICA) (1996b) South African Water Quality Guidelines. Volume 2. Recreational Use ( $2^{\text {nd }}$ edn.; $1^{\text {st }}$ issue). $88 \mathrm{pp}$.

DWAF (DEPARTMENT OF WATER AFFAIRS AND FORESTRY, SOUTH AFRICA) (1996c) South African Water Quality Guidelines. Volume 5. Agricultural Water Use: Livestock Watering ( $2^{\text {nd }}$ edn.; $1^{\text {st }}$ issue). $163 \mathrm{pp}$.

EADE J and SALLNOW MJ (1991) Introduction. In: Eade J and Sallnow MJ. (eds.) Contesting the Sacred: The Anthropology of Christian Pilgrimage. Urbana, University of Illinois. 1-29.

HORNE AJ and GOLDMAN CR (1994) Limnology (2 ${ }^{\text {nd }}$ edn.). McGraw-Hill, Inc. Singapore. 576 pp.

NATIONAL HERITAGE RESOURCES ACT. Act No. 25 of 1999. Republic of South Africa. Government Gazette No. 19974. Government Printers. Pretoria

NATIONAL WATER ACT. Act No. 36 of 1998. Republic of South Africa. Government Gazette No. 19182. Government Printers. Pretoria

REYNOLDS CS (1992) Chapter 9: Algae. In: Calow P and Petts GE (eds.) The Rivers Handbook: Hydrological and Ecological Principles Volume 1. Blackwell Scientific Publication, Oxford. 195-215.

ROOS JC and PIETERSE AJH (1995) Salinity and dissolved substances in the Vaal River at Balkfontein, South Africa. Hydrobiol. $30641-51$.

SARTORY DP and GROBBELAAR JU (1984) Extraction of Chlorophyll- $a$ from Freshwater Phytoplankton for Spectrophotometric Analysis. Hydrobiol. 114 177-187.

STANDARD METHODS (2005) Standard Methods for the Examination of Water and Wastewater $\left(21^{\text {st }} \mathrm{edn}\right.$.). Eaton $\mathrm{AD}$, Clesceri LS, Rice EW and Greenberg AE (eds.) American Public Health Association. American Water Works Association. Water Environment Federation p. 4-152-4-153.

WALLING DE and WEBB BW (1992) Chapter 3: Water Quality I. Physical Characteristics. In: Calow P and Petts GE (eds.) The Rivers Handbook: Hydrological and Ecological Principles Volume 1. Blackwell Scientific Publication, Oxford. 48-72.

WALMSLEY RD (2000) Perspectives in Eutrophication of Surface Waters: Policy/Research Needs in South Africa. WRC Report No. KV129/00. Water Research Commission, Pretoria, South Africa. $60 \mathrm{pp}$.

WRC (1998) Quality of Domestic Water Supplies. Volume 1. Assessment Guide $\left(2^{\text {nd }}\right.$ edn.). Department of Water Affairs and Forestry, /Department of Health, Water Research Commission. WRC Report No. TT101/98. Water Research Commission, Pretoria, South Africa. 104 pp.

WEBB BW and WALLING DE (1992) Chapter 4: Water Quality II. Chemical Characteristics. In: Calow P and Petts GE (eds.) The Rivers Handbook: Hydrological and Ecological Principles Volume 1. Blackwell Scientific Publication, Oxford. 73-100. 